Індивідуалізація підходів до методів індукції дозволить збільшити кількість вдалих прогнозів пологів та знизити частоту можливих ускладнень.

\title{
Література:
}

1. National Core Maternity Indicators Web report | Last updated: 18 Nov 2021 | Topic: Mothers \& babies | Citation AIHW Australian Institute of Health and Welfare (2021) National Core Maternity Indicators, AIHW, Australian Government, accessed 18 November 2021.

2. Queensland Health, Statistical Services Branch. Perinatal statistics Queensland. 2015.

3. Queensland Clinical Guidelines. Vaginal birth after caesarean section (VBAC). Guideline No. MN15.12-V4-R19. [Internet]. Queensland Health. 2015. [cited 2016 August 15]. Available from: http://www.health.qld.gov.au

4. Inducing labour. Clinical guideline Published: July 2018

Available from: http://www.nice.org.uk/guidance/cg70

5. Inducing labour NICE guideline Published: 4 November 2021 http://www.nice.org.uk/guidance/ng207

6. WHO recommendations: induction of labour at or beyond term World Health Organization 2018.

DOI https://doi.org/10.30525/978-9934-26-182-4-14

\section{МОНІТОРИНГ ВУГЛЕВОДНОГО І ЛІПІДНОГО ОБМІНУ У ХВОРИХ НА ЦУКРОВИЙ ДІАБЕТ 2 ТИПУ НА ТЛІ ГІПОТИРЕОЗУ $З$ УРАХУВАННЯМ СТАНУ МІКРОБІОЦЕНОЗУ КИШЕЧНИКА}

\author{
Остапенко К. I. \\ здобувач вищої освіти 2 курсу групи 1
}

спеціальності 224 - Технології медичної діагностики та лікування освітньої програми: «Лабораторна діагностика»

Національний фармачевтичний університет м. Харків, Украӥна

На сьогодні, актуальність проблеми пов язаної з цукровим діабетом обумовлена маштабністю розповсюдження. Діабет входить у трійку захворювань, які часто приводять до інвалідності та смертності [1]. 
Цукровий діабет 2 типу - хронічне ендокринно-обмінне захворювання, зумовлене відносною недостатністю інсуліну внаслідок поєднаного впливу різних ендогенних (генетичних) та екзогенних чинників, що призводять до порушення всіх видів обміну речовин, насамперед вуглеводного, ураження судин, нервів, різних органів і тканин. Специфічним обов'язковим проявом захворювання $\epsilon$ порушення вуглеводного обміну 3 прогресуючим наростанням рівня глюкози в крові і глюкозурією [2,3].

ЦД 2-го типу - найчастіша форма діабету $(\approx 80 \%)$, зумовлена поступовим порушенням секреції інсуліну в умовах інсулінорезистентності. Може бути генетично обумовленим (полігенне успадкування), однак ключову роль відіграють фактори середовища, а саме ожиріння особливо абдомінальне та низька фізична активність. Надмірна кількість вільних жирних кислот, які виділяє черевна жирова тканина, викликає «ліпотоксичність» - збільшене окиснення жирів, що призводить до гальмування гліколізу у м'язах, а у печінці призводить до посилення глюконеогенезу, що вимагає компенсаційної секреції інсуліну $\beta$-клітинами та може призвести до поступового виснаження їх резерву i порушення метаболізму глюкози $[4,5,6]$.

Цукровий діабет (ЦД) - одне 3 найпоширеніших захворювань 3 неухильною тенденцією до зростання. За даними ВООЗ, частота його в середньому коливається від 1,5 до 3-4\%, значно зростаючи в розвинутих країнах світу (до 5-6\%). При цьому майже 90\% припадає на хворих із ЦД 2 типу. У структурі ендокринних захворювань ЦД займає близько 60-70\%. Тепер у світі налічується близько 150 мільйонів хворих на діабет, в Україні - до 1 мільйона.4 Ураховуючи соціально-економічну й екологічну ситуацію в Україні, вірогідність непередбачуваного зростання ЦД, особливо 2 типу, дуже значна. Найбільший відсоток захворюваності спостерігається серед осіб з ожирінням $[7,8,9]$

Так, у людей $з$ помірним ступенем ожиріння частота діабету збільшується в 4 рази, з різко вираженим ожирінням - у 30 разів.7 Таким чином, ожиріння і похилий вік належать до основних чинників ризику, які зумовлюють схильність до розвитку діабету. Відомо, що ЦД 2 також збільшує ризик розвитку серцево-судинних захворювань й раку, що $\epsilon$ провідними причинами смертності цих пацієнтів. У цілому зростання поширеності цукрового діабету негативно впливає на численні фізіологічні функції, на стан органів та систем організму таких пацієнтів [10]. Враховуючи те, що гормони щитоподібної залози (ЩЗ) забезпечують енергетичний гомеостаз та беруть участь у дії інсуліну та регуляції глюкози, а також ряд досліджень про високий рівень поширеності 
порушень Щ3 у хворих на діабет, актуальним є дослідження порушень спільних ланок ліпідного та вуглеводного обміну [11].

Лікування тиреоїдними гормонами пацієнтів із поєднаними ЦД 2 та гіпотиреозом призводить до відновлення інсулінової чутливості та енергетичного гомеостазу. Однак надлишковий надходження тиреоїдних гормонів веде до зниження інсулінової чутливості, порушень вуглеводного та ліпідного обміну, що повинно враховуватися при розробці стратегії лікування ЦД 2 та дисфункцій щитовидної залози $[12,13]$.

За останні роки з'явилося безліч даних, що вказують на безпосередній зв'язок між змінами у складі мікробіоти кишечника та розвитком ожиріння, а також супутніх йому захворювань, насамперед цукрового діабету 2 типу. Для вироблення оптимальних методів лікування та профілактики даних захворювань необхідно структурувати наявні знання про механізми розвитку метаболічних порушень, роль у їх розвитку кишкової мікрофлори та можливі терапевтичні мішені $[14,15]$.

Мета дослідження: визначити особливості вуглеводного та ліпідного обміну у хворих на ЦД 2 типу у поєднанні з гіпотиреозом.

Матеріали та методи: у дослідження було включено 165 пацієнтів, які були розподілені на 3 групи. За нозологічними формами виявлено наступний розподіл захворювань обстежених хворих: перша група пацієнтів складалася з 57 хворих на цукровий діабет 2-го типу в поєднанні 3 первинним гіпотиреозом; друга група включала в себе 59 осіб, та була сформована 3 пацієнтів 3 цукровий діабет 2-го типу без патології щитовидної залози; третя група навпаки мала прояви гіпотиреозу без цукрового діабету та складалася з 30 осіб. Контрольна група налічувала 19 практично здорових осіб репрезентативного віку та статі. Означеним групам було проведено клініко-лабораторне обстеження згідно регламентуючих документів МОЗ України.

Результати досліджень: За результатами проведених досліджень встановлено, що у групі хворих на цукровий діабет у поєднанні 3 гіпотиреозом через 4 тижні комплексної терапії досягнуті поліпшення показників глюкози натще, постпрандіальної глікемії й гліколізованого гемоглобіну. Показано, що у хворих із поєднаною патологією отримані виражені порушення ліпідного обміну у вигляді збільшення значень тригліцеридів (ТГ), загального холестерину (ЗХС) та ліпопротеїнів низької щільності (ЛПНЩ), зниження рівнів холестеролу (ХС) та ліпопротеїнів високої щільності (ЛПВЩ), ніж у групах порівняння. Визначено, що на тлі комплексної терапії виявлена позитивна динаміка ліпідного спектра у вигляді зниження рівня ЗХС, ХС ЛПНЩ, коефіцієнта атерогенності (КА). Встановлено наявнісит позитивної кореляції між 
рівнями ЗХС, ТГ, КА та ТТГ (тиреотропним гормоном) у хворих на первинний гіпотиреоз.

Висновки: Дані проведено дослідження вказують вказує на необхідність ретельного скринінгу пацієнтів на цукровий діабет 2-го типу щодо можливої патології щитовидної залози, що дає змогу уникнути негативного сценарію розвитку поліендокринопатії. Означені підходи можуть бути корисними для етіопатогенетичних вивчення механізмів, у тому числі тих, що пов'язують цукровий діабет 2-го типу із захворюваннями щитовидної залози.

Виявлено дисбіотичні порушення у мікробіоценозі кишечника хворих на ЦД 2типу у поєднанні з гіпотиреозом, що виявилось у зниженні кількості біфідобактерій - у 54,9\% хворих, лактобактерій - у 42,2 \% пацієнтів, зниження вмісту у кишечнику кишкової палочки з незміненими властивостями - у 34,3 \% осіб, зростання кількості умовно-патогенних бактерій (K. pneumoniae, Proteus spp., E. aerogenes) 3 кількісними показниками більш ніж $10^{7} \mathrm{KУО} \mathrm{/} \mathrm{г} \mathrm{-} \mathrm{у} \mathrm{85,3} \mathrm{\% .} \mathrm{Гриби} \mathrm{Candida} \mathrm{albicans}$ було ізольовано у 70,6 \% обстежених у кількості більш ніж $10^{4}$ КУО / г, a у $17,6 \%$ пацієнтів було вилучено $S$. aureus, що вказує на необхідність корекції мікробіоценозу кишечника.

\section{Лiтература:}

1. Денесюк О.В., Денесюк В.І. «Внутрішня медицина Підручник для студентів закладів вищої медичної освіти III-IV рівня акредитації та лікарів післядипломної освіти на основі рекомендацій доказової медицини» // за ред. академіка НАМН України В.М. Коваленка. Київ: Моріон, 2019p.

2. Zheng Y., Ley S.H., Hu F.B., Global aetiology and epidemiology of type 2 diabetes mellitus and its complications // Nat Rev Endocrinol. 2018, 14(2): 88-98.

3. Picke A.K., Campbell G., Napoli N., Hofbauer L.C., Rauner M. Update on the impact of type 2 diabetes mellitus on bone metabolism and material properties // Endocr Connect. 2019; 8(3): 55-R70.

4. Пасечко Н.Н., Ярема Н.Н., Мартынюк Л., «Практичний посібник 3 внутрішньої медицини» Київ 2020 р, 373c.

5. Бобрик М. И. «Взаємний вплив тиреоїдного та вуглеводного обміну. Парадигми та парадокси» // Міжнародний ендокринологічний журнал. 2015. № 3 (67). 127-132.

6. Hussain S., Chowdhury T.A., The Impact of Comorbidities on the Pharmacological Management of Type 2 Diabetes Mellitus // Drugs. 2019, 79(3): 231-242. 
7. Панкив В. «Цукровий діабет: визначення, класифікація, епідеміологія, фактори ризику» // Міжнародний журнал єндокринології. 2013, №.7.55: 95-104.

8. Carrillo-Larco R.M., Barengo N.C., Albitres-Flores L., Bernabe-Ortiz A. The risk of mortality among people with type 2 diabetes in Latin America: A systematic review and meta-analysis of population-based cohort studies // Diabetes Metab Res Rev. 2019, 35(4): e3139.

9. Laakso M., «Biomarkers for type 2 diabetes» Mol Metab. 2019, Suppl. 27S: S139-S146.

10. Застосування антиоксидантного препарату Гепавал у раціональній терапії цукрового діабету / В. І. Паньків, І. В. Паньків // Міжнародний ендокринологічний журнал. 2018, 14(4): 358-361.

11. «Сучасний мультидисциплінарний підхід до діагностики та лікування хворих на цукровий діабет» // матеріали Всеукраїнської наук.практ. конф., 11- 12 травня 2017 р. - Тернопіль : ТДМУ, 2017. - 80 с.

12. "Classification and Diagnosis of Diabetes Mellitus: Standards of Medical Care in Diabetes» // Diabetes Care. 2018, 41: S13-S27.

13. «Classification of diabetes mellitus» World Health Organization. 2019, ISBN 978-92-4-151570-2.

14. Дисбіоз кишечника у хворих на цукровий діабет 2 типу та хронічний некалькульозний холецистит / Є. С. Сірчак, С. М. Сідей, В. В. Вайс // Здобутки клінічної і експериментальної медицини. 2018. № 2.-112-115.15. Мартишин О.О. " Цукровий діабет: класифікація, особливості, оцінка ризиків та діагностика», // за ред. «Украинского медицинского журнала» $2018 \mathrm{p}$.

15. Hooper L.V., Koh G.Y., Nagy A. The gut microbiota as an environmental factor 128 that regulates fat storage. Proc Natl Acad Sci U S A. 2004; 101:15718-15723. 